\title{
The Effects of Biochar on Indigenous Arbuscular Mycorrhizae Fungi from Agroenvironments
}

\author{
María Videgain-Marco ${ }^{1, *(\mathbb{D})}$, Pedro Marco-Montori ${ }^{2}{ }^{\mathbb{D}}$, Clara Martí-Dalmau ${ }^{1}\left(\mathbb{D}\right.$, María del Carmen Jaizme-Vega ${ }^{3}$, \\ Joan Josep Manyà-Cervelló ${ }^{4}(\mathbb{D})$ and Francisco Javier García-Ramos ${ }^{1,5}$ (D) \\ 1 Departamento de Ciencias Agrarias y del Medio Natural, EPS, Universidad de Zaragoza, \\ Carretera de Cuarte s/n, E-22071 Huesca, Spain; cmarti@unizar.es (C.M.-D.); fjavier@unizar.es (F.J.G.-R.) \\ 2 Centro de Investigación y Tecnología Agroalimentaria de Aragón (CITA), Instituto Agroalimentario de \\ Aragón-IA2 (CITA-Universidad de Zaragoza), Unidad de Recursos Forestales, Avenida Montañana 930, \\ E-50059 Zaragoza, Spain; pmarcomo@cita-aragon.es \\ 3 Departamento de Protección Vegetal, Instituto Canario de Investigaciones Agrarias (ICIA), \\ Carretera de El Boquerón s/n, Valle Guerra, La Laguna, E-38270 Tenerife, Spain; mcjaizme@icia.es \\ 4 Thermochemical Processes Group, Aragón Institute of Engineering Research (I3A), EPS, \\ University of Zaragoza, Carretera de Cuarte s/n, E-22071 Huesca, Spain; joanjoma@unizar.es \\ 5 Instituto Agroalimentario de Aragón-IA2 (CITA-Universidad de Zaragoza), EPS, Universidad de Zaragoza, \\ Carretera de Cuarte s/n, E-22071 Huesca, Spain \\ * Correspondence: mvidegain@unizar.es; Tel.: +34-974292656
}

Citation: Videgain-Marco, M.; Marco-Montori, P.; Martí-Dalmau, C.; Jaizme-Vega, M.d.C.; Manyà-Cervelló, J.J.; García-Ramos, F.J. The Effects of Biochar on Indigenous Arbuscular Mycorrhizae Fungi from Agroenvironments. Plants 2021, 10, 950. https://doi.org/10.3390/ plants10050950

Academic Editors: Parvaiz Ahmad, Mirza Hasanuzzaman, Luigi Sanita' di Toppi and Aziz Aziz

Received: 28 February 2021

Accepted: 4 May 2021

Published: 10 May 2021

Publisher's Note: MDPI stays neutral with regard to jurisdictional claims in published maps and institutional affiliations.

Copyright: (c) 2021 by the authors. Licensee MDPI, Basel, Switzerland. This article is an open access article distributed under the terms and conditions of the Creative Commons Attribution (CC BY) license (https:/ / creativecommons.org/licenses/by/ $4.0 /)$.

\begin{abstract}
The effects of biochar on soil-plant-microorganisms systems are currently being extensively investigated. Considering that arbuscular mycorrhizal fungi (AMF) play an essential role in nutrient dynamics, the present study aims at understanding vine shoot-derived biochar effects on AMF activity and the impact of their multiplication in soils on water-stress resistance of plants. Three agronomic tests were performed in greenhouse pots. The first experiment evaluated the effects of three factors: final pyrolysis temperature for biochar production $\left(400^{\circ} \mathrm{C}\right.$ and $\left.600{ }^{\circ} \mathrm{C}\right)$, application rate $(0$ weight-wt.$\%$ as a control, $1.5 \mathrm{wt}$ \%, and $3.0 \mathrm{wt}$. \%) and texture of the growing media (sandy-loam and clay-loam origin) on AMF, microbial communities and phosphatase activity. In the second experiment, an indigenous consortium of AMF was multiplied through the solid substrate method and sorghum as a trap plant with biochar addition. This process was compared to a control treatment without biochar. Obtained inocula were tested in a third experiment with lettuce plants under different water irrigation conditions. Results from the first experiment showed a general increase in AMF activity with the addition of the biochar produced at $400{ }^{\circ} \mathrm{C}$ in the sandy-loam texture substrate. Results of the second experiment showed that the biochar addition increased AMF root colonization, the number of AMF spores and AMF infective potential. Results of the third experiment showed that biochar-derived AMF inoculum increased AMF root colonization, AMF spores, dry biomass and the SPAD index in a lettuce crop under low-water irrigation conditions.
\end{abstract}

Keywords: vine-shoots; sorghum; lettuce; drought stress; trap plant; waste management

\section{Introduction}

New crop varieties and biotechnologies are being investigated in dealing with droughtstress events in agriculture [1]. Concurrently, indigenous crop varieties and their adaptation mechanisms have been valued as agroecological strategies that contribute to improving drought resistance in rainfed areas. Improving the physical and biological fertility of the soil is becoming a mandatory practice to preserve its productive capacity, even though chemical fertilization remains the focus of intensive agricultural systems.

Currently, one of the most studied organic amendments to enrich soil fertility is biochar, a carbon-rich product obtained by thermal degradation of biomass under a limited supply of oxygen, at temperatures usually below $700{ }^{\circ} \mathrm{C}$, which is produced to be added to the soil as a means of improving its quality and increasing carbon storage [2]. 
Previous studies have already reported that biochar is highly recalcitrant and able to improve some soil properties by influencing biochemical and biological processes [2-5]. Biochar amendment significantly enhances the nutrient availability and nutrient retention of a wide range of soils [6], in addition to the positive contribution to the improvement of other physical and biological soil properties [7-10] and to metal retention [11]. However, the capacity of this material to provide or enhance soil fertility extremely depends on the type of feedstock and pyrolysis conditions [12].

The effects of biochar (when it is used as a soil amendment) on the soil-plantmicroorganisms system are currently being extensively investigated. Since microorganisms play an essential role in soil nutrient dynamics, they can be used as bioindicators due to their high sensitivity to small short-term habitat modifications. Furthermore, microorganisms have high resilience to degradation processes and biotic/abiotic stresses [13].

Droughts are a limiting factor in agricultural production. In addition, due to climate change, droughts are increasing in frequency and severity in some regions [14]. Alleviation of this abiotic stress through the enhancement of the arbuscular mycorrhizal fungi (AMF) presence in soils could be an interesting agroecological strategy, since AMF can shape the adaptative strategy of plants. The most important mechanisms by which symbiosis can alleviate drought stress in host plants are related to the direct uptake of water through the fungal hyphae, changes in soil water retention properties, better osmotic adjustment of AM plants, enhancement of plant gas exchange and water-use efficiency, and protection against oxidative damage generated by drought $[15,16]$.

Research studies involving biochar and AMF processes show a wide spectrum of results, depending on experimental conditions, biochar composition and particle size [17]. The indigenous AMF consortia in soils are usually selected as bioindicators, since they are considered crucial components of soil fertility, either due to symbiotic relationships with plant roots or interactions with rhizosphere microorganisms [18]. Some earlier studies reported negative effects of biochar addition on AMF root colonization for both indigenous AMF consortia and introduced species. Warnock et al. [19] reported a decrease in the AMF abundance with wood-based biochar addition accompanied by changes in phosphorous availability. In line with this, several research studies reported negative or no significant effects $[20,21]$ of biochar on AMF development. But there is a clear interaction between biochar, microorganisms, mineral nutrients available in the soil and water conditions. LeCroy et al. [22] showed that biochar reduced biomass production of sorghum plants in the presence of high levels of nitrogen fertilizer; they suggested that soil nitrogen controls the ability of char to influence the mycorrhizal symbiosis and the degree to which the fungi oxidize the char surface. Vanek and Lehmann [23] found that positive biochar-AMF interactive effects on bean phosphorus (P) uptake were fostered by sparingly soluble Fe-P; however, they were not observed when soluble $\mathrm{P}$ was combined with biochar. In this sense, Blackwell et al. [24] and Solaiman et al. [25] also correlated AMF increases to low nutrients availability in soil. Hammer et al. [26] observed AM fungal hyphae accessing microsites within biochar mediating plant $P$ uptake from the biochar surface.

Considering the wide range of results reported in the literature, the possibility of using biochar as a component of the growing media in containerized plant production [27] and its utility as a potential carrier material for delivery inoculants [28], assessing the suitability of biochar as a component of the growing media on the multiplication process of an indigenous consortium of AMF is proposed herein. For this purpose, a first bioassay was conducted in pots under controlled greenhouse conditions. Sorghum (Sorghum bicolor L. Moench) was selected as a classic mycotrophic test crop to evaluate the effect of the addition of two types of vine shoot-derived biochar on the AMF activity and other biological indicators (i.e., phosphatase activity and microbial community variations). The experiment measured the influence of different factors (the final pyrolysis temperature at which the biochar was produced, application rate and growing media substrate texture). Based on the results of the abovementioned bioassay, it was hypothesized that biochar could be suitable as a component of the growing media on the multiplication process of indigenous AMF 
consortia in soils through the method of solid substrate and trap plants [29]. This approach was tested experimentally, and the final inoculum obtained was then evaluated in terms of water-stress resistance for lettuce (Lactuca sativa) plants, which were grown in the same soil under study.

\section{Results}

\subsection{Biochar Properties}

The complete characterization of the two types of biochar produced is detailed in a previous publication [30]. The results were primarily dependent on pyrolysis operating conditions. The biochar average mass yield $\left(Y_{\text {char }}\right)$ notably decreased when the pyrolysis final temperature increased (biochar at $400{ }^{\circ} \mathrm{C}-y_{\text {char }}=0.38$; biochar at $600{ }^{\circ} \mathrm{C}-y_{\text {char }}=0.29$ ). The biochar produced at $600{ }^{\circ} \mathrm{C}$ (B600) had a higher fixed carbon content measured on a dry basis (84.54 wt. \%) and ash (10.02 wt. \%) compared to biochar produced at $400{ }^{\circ} \mathrm{C}$ (B400: $70.88 \mathrm{wt}$. \% and $6.45 \mathrm{wt}$ \% respectively), which conversely had a higher amount of volatile matter $(+19.64 \mathrm{wt}$. \%). The specific surface area and pore volume increased with rising pyrolysis final temperature. Related to it, water-holding capacity (WHC) increased with pyrolysis final temperature, from 14.16 v.\% in B400 to 18.35 v.\% in B600. Principal and secondary nutrient levels showed no major differences between B400 and B600. Table S1 (Supplementary Material) details the results from proximate, elemental and physicochemical analyses of the biochar produced.

\subsection{Soils Characterization}

Results from the AMF infective potential of soils and microbiological analyses are summarized in Table 1.

Table 1. AMF infective potential and microbiological composition of soils.

\begin{tabular}{|c|c|c|c|}
\hline Determination $^{1}$ & Unit & $S 1^{2}$ & S2 \\
\hline AMF potential (MPN) & $\begin{array}{c}\text { Number of infective } \\
\text { mycorrhizal } \\
\text { propagules } \\
100 \mathrm{~cm}^{3-1}\end{array}$ & $39.6 \pm 9.3$ & $30.9 \pm 13.1$ \\
\hline $\begin{array}{l}\text { Number of AMF } \\
\text { spores }\end{array}$ & $\begin{array}{c}\text { Number of AMF } \\
\text { spores } \\
100 \mathrm{~g} \mathrm{soil}^{-1}\end{array}$ & $420 \pm 18$ & $465 \pm 23$ \\
\hline Identified genera & $\%$ spores & $\begin{array}{l}20 \text { Gigaspora spp. } \\
3 \text { Scutellospora spp. } \\
77 \text { Glomus spp. }\end{array}$ & $\begin{array}{l}6 \text { Acaulospora spp. } \\
94 \text { Glomus spp. }\end{array}$ \\
\hline \multicolumn{4}{|l|}{$\begin{array}{c}\text { Culturable microbial } \\
\text { communities }\end{array}$} \\
\hline $\begin{array}{l}\text { Mesophilic aerobic } \\
\text { microorganisms }\end{array}$ & $\log \mathrm{cfu} \mathrm{g}^{-1}$ & $6.59 \pm 0.90$ & $7.08 \pm 0.67$ \\
\hline Actinomycetes & $\log \mathrm{cfu}^{-1}$ & $6.08 \pm 0.45$ & $6.45 \pm 0.27$ \\
\hline Pseudomonas genus & $\log \mathrm{cfu}^{-1}$ & $5.74 \pm 0.13$ & $5.96 \pm 0.34$ \\
\hline Mycobiota & $\log \mathrm{cfu}^{-1}$ & $4.75 \pm 0.65$ & $4.71 \pm 0.43$ \\
\hline
\end{tabular}

${ }^{1}$ Results from five replicates of each sample of soil. Average values and standard deviation. ${ }^{2}$ S1-soil 1 : sandy-loam; S2-soil 2: clay-loam.

Student $t$-test did not show statistical differences between Soil 1 and Soil 2 for the biological characteristics analyzed.

The AMF infective potential showed mean values of 39.6 and 30.9 propagules in $100 \mathrm{~cm}^{3}$ of soil, for sandy-loam soil (S1) and clay-loam soil (S2), respectively. The initial mean number of AMF spores was 420 spores in S1 and 465 spores in S2. The morphological identification of the spores reveled that Glomus spp. was the main species identified in the 
samples of both soils (77\% in S1 and 94\% in S2). This species is largely found in natural and cultivated ecosystems and stands out for its high efficiency on a large number of crops and its adaptation to a wide $\mathrm{pH}$ range [31]. In addition, it was detected, in lower percentages, the availability of other species such as Gigaspora spp. (20\% in S1), Scutelloespora spp. ( $3 \%$ in S1) and Acaullospora spp. (6\% in S2).

With respect to the culturable microbial communities, soils achieved an average initial total microbial count, mesophilic aerobic microorganisms (MAM), of 7.5 and $8.0 \log$ cfu $\mathrm{g}^{-1}$, for sandy-loam and clay-loam substrates, respectively. The predominant microbial group in both soils was actinomycetes (ACT) (6.1 and $6.5 \log \mathrm{cfu} \mathrm{g}^{-1}$, respectively for each substrate), followed by Pseudomonas genus (PS) (5.7 and $6.0 \mathrm{log} \mathrm{cfu} \mathrm{g}^{-1}$, for sandy-loam and clay-loam substrates, respectively). The mycobiota (molds and yeasts) was present at relatively lower numbers with average counts of $4.7 \mathrm{cfu} \mathrm{g}^{-1}$ for both substrates.

Results from physicochemical fertility of Soil 1 and Soil 2 are shown in Table S2 (Supplementary Material). The main differences between both samples were found in the content of oxidable organic matter (S1: $3.04 \mathrm{wt}$ \%; S2: $1.70 \mathrm{wt}$ \%), macroelements content (mg kg ${ }^{-1}: \mathrm{N}_{-} \mathrm{NO}_{3}$ : S1-59, S2-12; P Olsen: S1-32, S2-29; K: S1-160, S2-252) and WHC (S1-5.41 v. \%; S2-10.22 v. \%).

2.3. Experiment 1: Effects of Soil Texture, Addition Rates and Final Pyrolysis Temperatures on AMF Performance, Microbial Communities' Variation and Phosphatase Activity

During crop development, a general increase in root AMF colonization was observed from 210 to 330 days after sowing $\left(\mathrm{D}_{210}\right.$ and $\left.\mathrm{D}_{330}\right)$; the average values of AMF root colonization decreased in the last period, which could be related to winter temperatures and the final development of the crop. The average values measured and standard deviation for this parameter and the number of AMF spores at the final of the experiment are summarized in Table 2.

No differences on root colonization were observed for the measurements performed during the first seven months of the experiment (from $D_{120}$ to $D_{210}$ ) in either of the two types of growing media.

Significant differences in root colonization were observed in measurements made from $\mathrm{D}_{330}$. For both sandy-loam and clay-loam substrates, the highest percentage of colonization was observed in the treatment with B400 addition $(20.0 \%$ and $31.7 \%$ for S1 and S2 respectively), although there were no differences in comparison to Control treatment for the clay-loam substrate. This trend between the treatments was maintained up to the last measurement date $\left(\mathrm{D}_{390}\right)$ with lower average colonization values, as mentioned above. It should be noted that there was a marked decline of AMF root colonization in B600 treatments with lower doses in S1 (from 10\% to 5\%) and with high doses in S2 (from 18.3\% to $6.7 \%)$ at the end of the experiment $\left(\mathrm{D}_{390}\right)$.

The number of AMF spores at the end of the experiment $\left(\mathrm{D}_{390}\right)$ had significantly different results between treatments (see Table 2). In particular, a clear influence of biochar addition in the sandy-loam substrate in comparison to Control treatment was observed. The highest value in this substrate was reported in B400 at high doses of biochar addition (1511 spores per $100 \mathrm{~g}$ of soil) with no significative differences with respect to B600 treatments (1380 and 1095 spores per $100 \mathrm{~g}$ of soil in D1 and D2 treatments, respectively). Concerning the clay-loam substrate, no differences were observed in the number of AMF spores between treatments with the exception of B600 at a high dose of biochar addition (5245 spores per $100 \mathrm{~g}$ of soil). Identified genera information is available in Table S3. No differences were observed between treatments for genera distribution at the end of the experiment. 


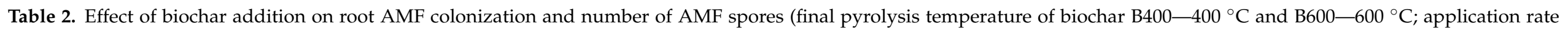
D0—Control without biochar, D1-1.5 wt. \%, D2—3 wt. \%). Average values and standard deviation (in brackets).

\begin{tabular}{|c|c|c|c|c|c|c|c|c|c|c|c|}
\hline \multirow{3}{*}{\multicolumn{2}{|c|}{ Variable Measured }} & \multicolumn{5}{|c|}{ Sandy-Loam Substrate } & \multicolumn{5}{|c|}{ Clay-Loam Substrate } \\
\hline & & \multirow{2}{*}{ D0 } & \multicolumn{2}{|c|}{ B400 } & \multicolumn{2}{|c|}{ B600 } & \multirow{2}{*}{ Do } & \multicolumn{2}{|c|}{ B400 } & \multicolumn{2}{|c|}{ B600 } \\
\hline & & & D1 & D2 & D1 & D2 & & D1 & D2 & D1 & D2 \\
\hline \multirow{4}{*}{$\begin{array}{c}\text { Root AMF } \\
\text { colonization } \\
\%\end{array}$} & $\mathrm{D}_{120}$ & $\begin{array}{l}10.0 \mathrm{a} \\
(1.0)\end{array}$ & $\begin{array}{c}13.3 \mathrm{a} \\
(5,7)\end{array}$ & $\begin{array}{l}12.5 \mathrm{a} \\
(1.0)\end{array}$ & $\begin{array}{c}10.0 \mathrm{a} \\
(1.5)\end{array}$ & $\begin{array}{c}10.0 \mathrm{a} \\
(1.5)\end{array}$ & $\begin{array}{c}10.5 \mathrm{a} \\
(2.0)\end{array}$ & $\begin{array}{l}13.3 \mathrm{a} \\
(6.7)\end{array}$ & $\begin{array}{c}10.0 \mathrm{a} \\
(0.0)\end{array}$ & $\begin{array}{c}11.6 \mathrm{a} \\
(4.0)\end{array}$ & $\begin{array}{c}13.3 \mathrm{a} \\
(5.7)\end{array}$ \\
\hline & $\mathrm{D}_{210}$ & $\begin{array}{c}11.7 \mathrm{a} \\
(2.8)\end{array}$ & $\begin{array}{c}18.3 \mathrm{a} \\
(5.7)\end{array}$ & $\begin{array}{l}16.7 \mathrm{a} \\
(2.9)\end{array}$ & $\begin{array}{l}11.7 \mathrm{a} \\
(2.8)\end{array}$ & $\begin{array}{c}13.3 \mathrm{a} \\
(2.9)\end{array}$ & $\begin{array}{l}21.7 \mathrm{a} \\
(5.7)\end{array}$ & $\begin{array}{l}21.7 \mathrm{a} \\
(5.7)\end{array}$ & $\begin{array}{l}13.3 \mathrm{a} \\
(28.9)\end{array}$ & $\begin{array}{c}13.3 \mathrm{a} \\
(2.8)\end{array}$ & $\begin{array}{c}15.0 \mathrm{a} \\
(0.0)\end{array}$ \\
\hline & $\mathrm{D}_{330}$ & $\begin{array}{l}8.3 \mathrm{~b} \\
(2.9)\end{array}$ & $\begin{array}{c}13.3 \mathrm{ab} \\
(2.9)\end{array}$ & $\begin{array}{c}20.0 \mathrm{a} \\
(0.0)\end{array}$ & $\begin{array}{c}10.0 \mathrm{~b} \\
(5.0)\end{array}$ & $\begin{array}{c}11.7 \mathrm{ab} \\
(2.9)\end{array}$ & $\begin{array}{c}26.7 \mathrm{ab} \\
(2.9)\end{array}$ & $\begin{array}{c}26.7 \mathrm{ab} \\
(7.3)\end{array}$ & $\begin{array}{l}31.7 \mathrm{a} \\
(2.9)\end{array}$ & $\begin{array}{c}26.7 \mathrm{ab} \\
(2.9)\end{array}$ & $\begin{array}{c}18.3 \mathrm{~b} \\
(2.9)\end{array}$ \\
\hline & $\mathrm{D}_{390}$ & $\begin{array}{c}5.7 \mathrm{bc} \\
(1.1)\end{array}$ & $\begin{array}{c}13.3 \mathrm{ab} \\
(2.9)\end{array}$ & $\begin{array}{l}18.3 \mathrm{a} \\
(2.9)\end{array}$ & $\begin{array}{l}5.0 \mathrm{c} \\
(0.0)\end{array}$ & $\begin{array}{c}10.0 \mathrm{bc} \\
(0.0)\end{array}$ & $\begin{array}{c}25.0 \mathrm{a} \\
(0.0)\end{array}$ & $\begin{array}{c}23.3 \mathrm{a} \\
(2.9)\end{array}$ & $\begin{array}{c}31.6 \mathrm{a} \\
(2.9)\end{array}$ & $\begin{array}{c}25.0 \mathrm{a} \\
(0.0)\end{array}$ & $\begin{array}{l}6.7 \mathrm{~b} \\
(5.8)\end{array}$ \\
\hline $\begin{array}{l}\text { Number of } \\
\text { AMF spores } \\
100 \mathrm{~g} \mathrm{soil}^{-1}\end{array}$ & $\mathrm{D}_{390}$ & $\begin{array}{l}548 \mathrm{c} \\
(103)\end{array}$ & $\begin{array}{c}830 \mathrm{bc} \\
(198)\end{array}$ & $\begin{array}{c}1511 \mathrm{a} \\
(170)\end{array}$ & $\begin{array}{c}1380 \mathrm{ab} \\
(275)\end{array}$ & $\begin{array}{c}1095 \mathrm{ab} \\
(230)\end{array}$ & $\begin{array}{c}1668 \mathrm{~b} \\
(200)\end{array}$ & $\begin{array}{c}2058 \mathrm{~b} \\
(232)\end{array}$ & $\begin{array}{c}1930 \mathrm{~b} \\
(287)\end{array}$ & $\begin{array}{c}1978 \mathrm{~b} \\
(95)\end{array}$ & $\begin{array}{l}5245 \mathrm{a} \\
(1399)\end{array}$ \\
\hline
\end{tabular}

Means within a row followed by the same letter are not significantly different for the same kind of growing substrate at $p \leq 0.05$ (Tukey's test). 
MAM and PS were the microbial communities in which significant differences were observed after biochar addition. As shown in Figure 1, the overall average value of MAM increased slightly from the initial counts, and the biochar application significantly increased the average values in the sandy-loam substrate, from $7.5 \mathrm{cfu} \mathrm{g}^{-1}$ in Control treatment to $8.2 \mathrm{cfu} \mathrm{g}^{-1}$ after biochar addition. For this texture soil, PS counts showed the highest values when B400 was added. In S1, B400 and B600 showed similar effects. B400 increased the average value in comparison to Control treatment for this texture soil. However, no differences were observed for these microbial communities under biochar addition in the clay-loam substrates.

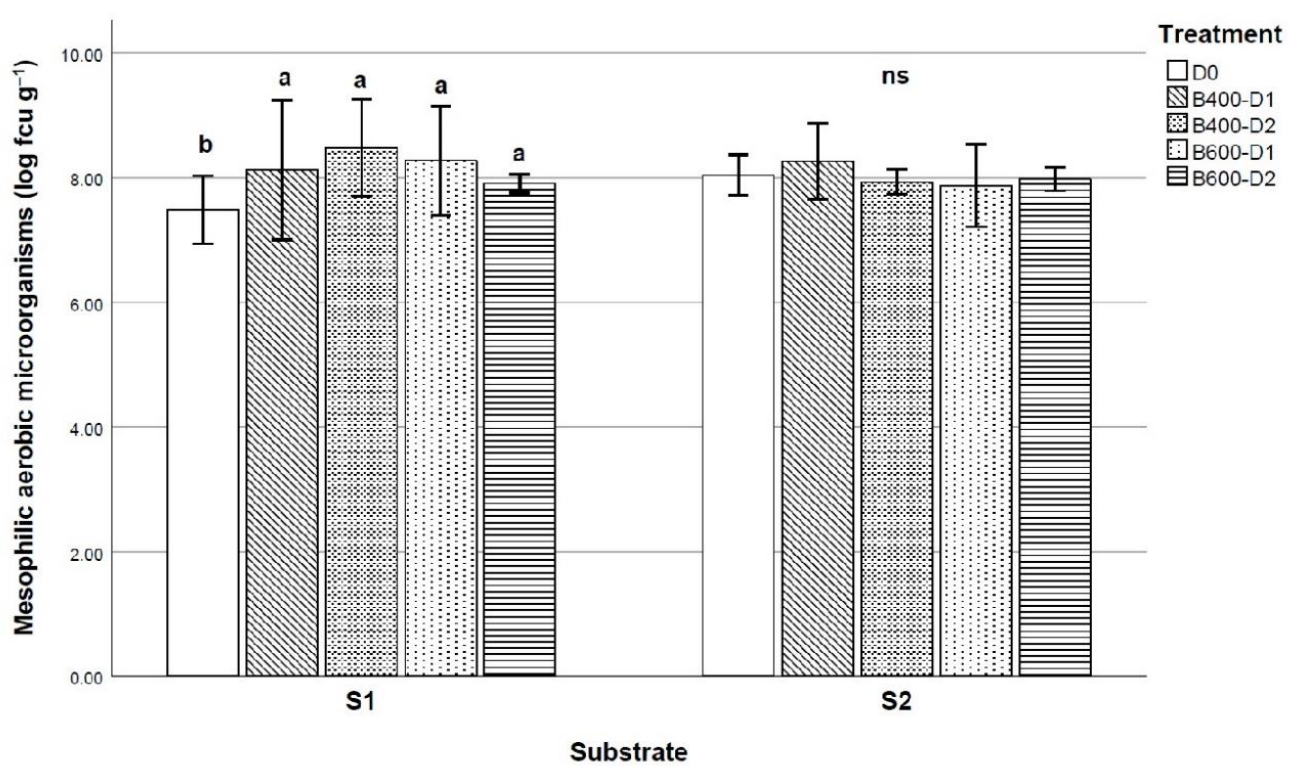

(a)

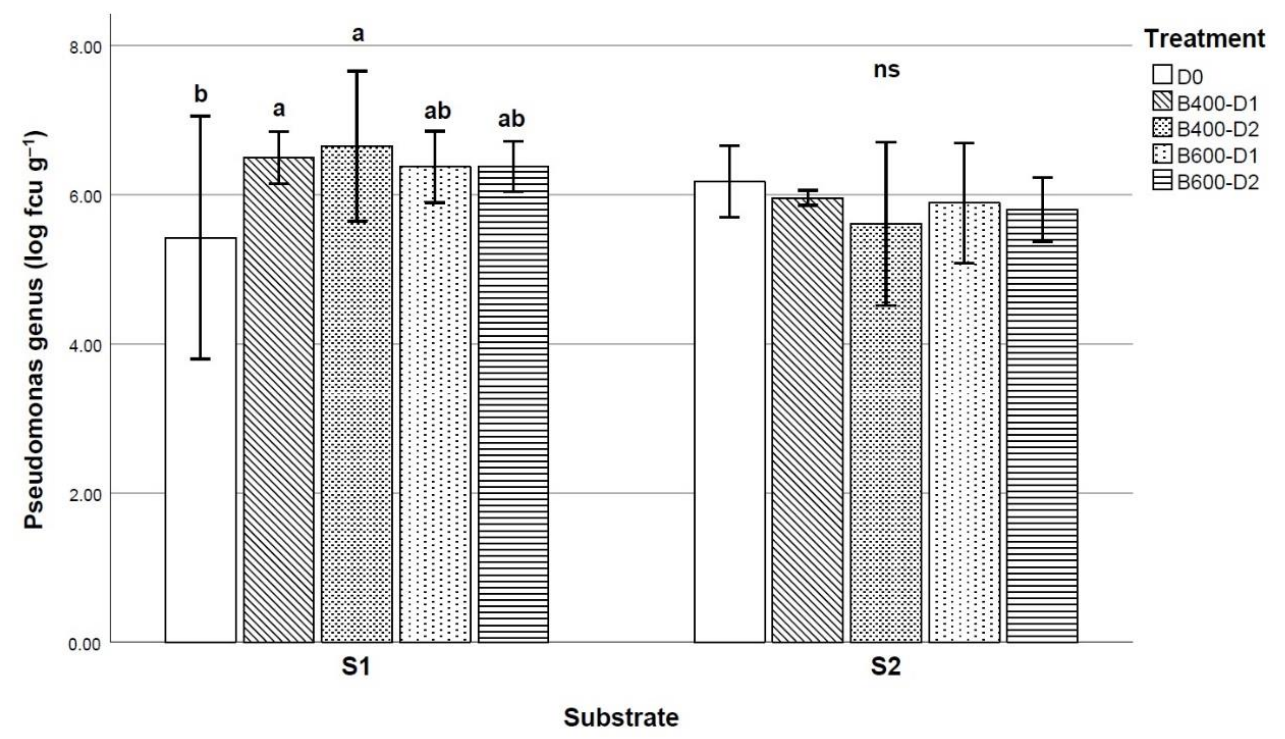

(b)

Figure 1. Effect of biochar application on (a) mesophilic aerobic microorganisms and (b) Pseudomonas genus. (Final pyrolysis temperature of biochar B400-400 ${ }^{\circ} \mathrm{C}$ and B $600-600^{\circ} \mathrm{C}$; D0-Control without biochar, D1-1.5 wt. \%, D2-3 wt. \%; S1—sandy-loam substrate, S2-clay-loam substrate). Different letters show statistically significant differences at $p \leq 0.05$ (Tukey's test). 
Complete counts of the mesophilic aerobic microorganisms, Pseudomonas genus, actinomycetes, and mycobiota (yeasts and molds) are detailed in Table S3. The statistical analysis of microbiological counts performed in substrates at the end of the experiment $\left(\mathrm{D}_{390}\right)$ did not show significant differences in actinomycetes and mycobiota populations. The final values were similar to those measured during the initial characterization.

For the specific results of our experiment, no differences in $\mathrm{P}$ content were found on substrates or plant tissue [30]; however, a positive correlation between AMF activity and Pseudomonas abundance was confirmed for the sandy-loam substrate (see Table S4).

Enzymatic activities have an important function in organic $\mathrm{P}$ mineralization and in $\mathrm{P}$ plant nutrition, especially in calcareous soils subjected to frequent retrogression processes of available P [32]. For all the substrates and biochar application rates assessed herein, the AcdP activity values $\left(1.38 \mu \mathrm{mol} \mathrm{h}{ }^{-1}\right.$ in average $)$ were lower than AlkP ones $(2.98 \mu \mathrm{mol}$ $\mathrm{h}^{-1} \mathrm{~g}^{-1}$ in average). This finding, however, was somewhat expected, since microbial population in soils can be sensitive to the growing $\mathrm{pH}$ media of both soils sampled for substrate preparation.

From the analysis of the phosphatase activity in relation to substrate granulometry, it was deduced that, for the sandy-loam substrate, both AcdP and AlkP values had similar behavior (see Figure 2), leading to significant activity increases with the addition of B600 in comparison with B400. Both AcdP and AlkP values did not show significant differences between B400 and Control treatment in the sandy-loam substrate (S1).

Nevertheless, for the clay-loam substrate (S2), AcdP only showed significant differences in B600 treatment; in contrast, the highest main value of AlkP in S2 was obtained for the Control treatment without biochar, which had results significantly differents from treatments with biochar. In this texture (S2), the lower dose of biochar addition was related to a decrease in AlkP activity, both with B400 and B600 addition. The complete results are detailed in Table S3.

Table 3 shows the results from the three-way ANOVA on the significant effects of the factors (i.e., growing substrate texture, biochar final temperature, and application rate) on root AMF colonization at different dates after sowing $\left(\mathrm{D}_{210}, \mathrm{D}_{330}\right.$ and $\left.\mathrm{D}_{390}\right)$, number of AMF spores, phosphatase activity and microbial communities at the end of the second crop development cycle $\left(\mathrm{D}_{390}\right)$.

As can be seen from the results reported above, the growing-substrate medium was the most influential factor for the response variables assessed. Results obtained in S1 demonstrate that biochar addition had the greatest positive influence in fine texture, in terms of AMF root colonization, number of AMF spores and enzymatic activity. Biochar temperature also had an important effect, with a positive trend in AMF root colonization under B400 addition. Application rate had the lower effect considering it separately (only significant in enzymatic activities); however, significant effects were observed by the interactions with biochar on the studied variables.

Considering these results, B400 was selected as a component of the solid substrate used in Experiment 2 to multiply the AMF consortium present in the sandy-loam substrate (S1). The amount of biochar selected to prepare the multiplication substrate was $1.5 \mathrm{wt}$. \%, since this concentration value could be relatively easily implemented in real field conditions. 


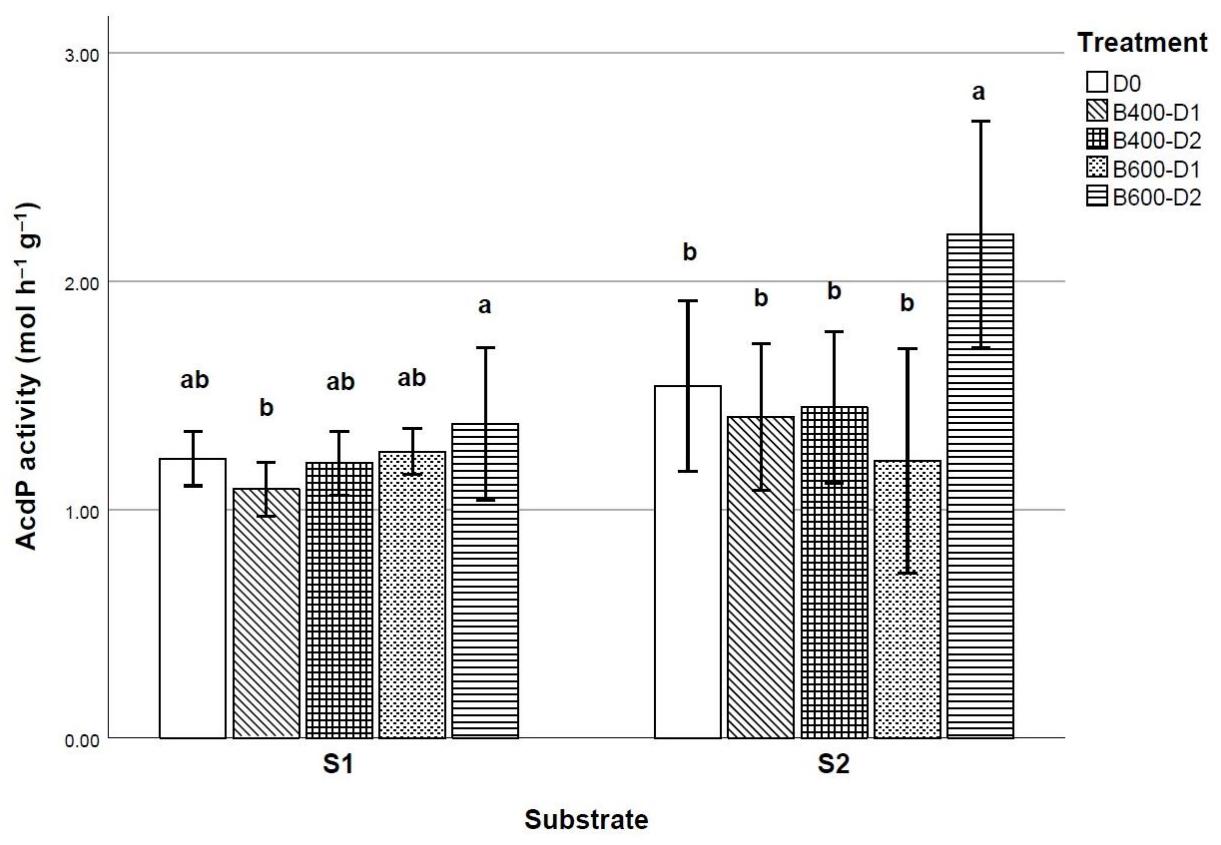

(a)

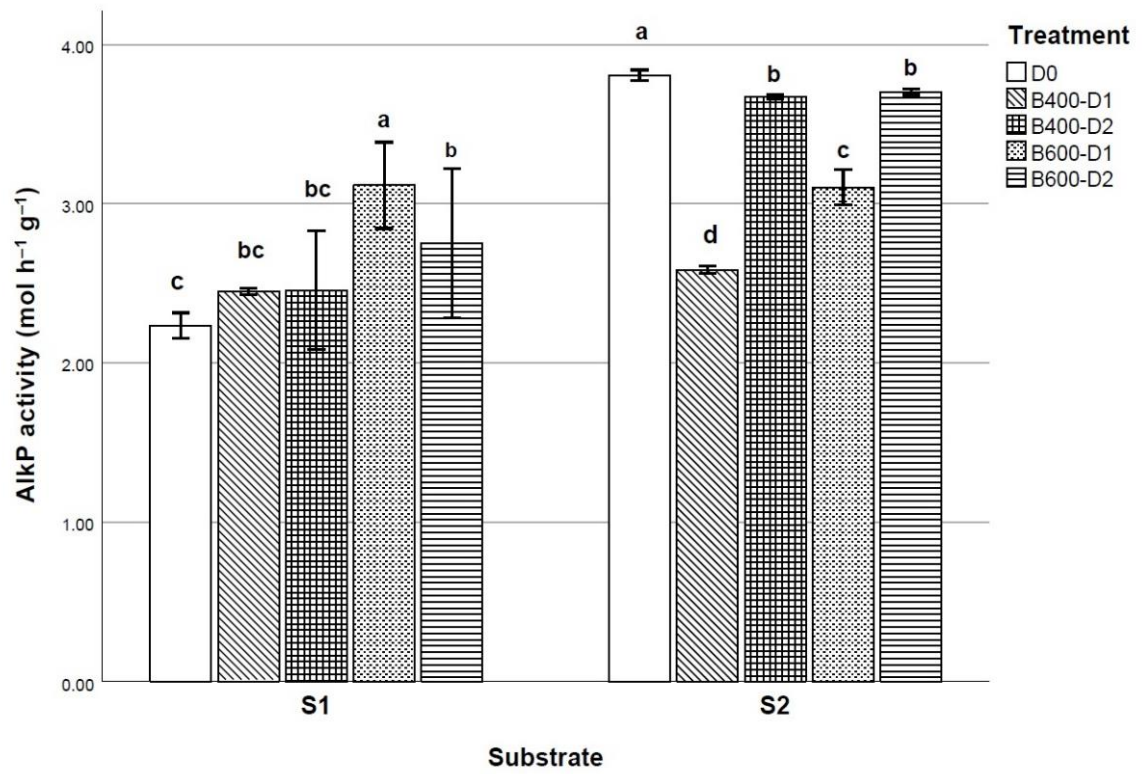

(b)

Figure 2. Effect of biochar application on (a) acid phosphatase activity and (b) alkaline phosphatase activity. (Final pyrolysis temperature of biochar B400-400 ${ }^{\circ} \mathrm{C}$ and B600-600 ${ }^{\circ} \mathrm{C}$; D0-Control without biochar, D1-1.5 wt. \%, D2-3 wt. \%; S1—sandy-loam substrate, S2—clay-loam substrate). Different letters show statistically significant differences at $p \leq 0.05$ (Tukey's test). 
Table 3. Three-way ANOVA results on the effects of growing substrate texture, biochar temperature and application rate on root AMF colonization, number of AMF spores, phosphatase activities and microbial communities.

\begin{tabular}{|c|c|c|c|c|c|c|c|c|}
\hline \multirow{2}{*}{ Factor } & \multicolumn{3}{|c|}{ Root AMF Colonization } & \multirow{2}{*}{ AMF Spores } & \multicolumn{2}{|c|}{ Phosphatase Activity } & \multicolumn{2}{|c|}{ Microbial Communities } \\
\hline & $D_{210}$ & $\mathrm{D}_{330}$ & $D_{390}$ & & AcdP & AlkP & MAM & PS \\
\hline $\begin{array}{c}\text { Growing } \\
\text { substrate } \\
\text { texture (S) }\end{array}$ & & $<0.0001$ & $<0.0001$ & $<0.0001$ & $<0.0001$ & $<0.0001$ & & 0.040 \\
\hline $\begin{array}{l}\text { Biochar } \\
\text { temperature } \\
\text { (B) }\end{array}$ & & 0.001 & $<0.0001$ & & 0.001 & $<0.0001$ & & $<0.0001$ \\
\hline $\begin{array}{l}\text { Application } \\
\text { rate (D) }\end{array}$ & & & & & $<0.0001$ & $<0.0001$ & & \\
\hline $\mathrm{S} \times \mathrm{B}$ & & & & & & 0.006 & & 0.012 \\
\hline $\mathrm{S} \times \mathrm{D}$ & & & 0.002 & & 0.006 & $<0.0001$ & & \\
\hline $\mathrm{B} \times \mathrm{D}$ & 0.048 & 0.007 & $<0.0001$ & 0.005 & 0.001 & & & 0.001 \\
\hline $\mathrm{S} \times \mathrm{B} \times \mathrm{D}$ & & & $<0.0001$ & 0.003 & 0.001 & & 0.011 & \\
\hline
\end{tabular}

$\mathrm{D}_{210 / 330 / 390}$ : days after sowing; AcdP: Acid phosphatase activity: AlkP: Alkaline phosphatase activity; MAM: mesophilic aerobic microorganisms; PS: Pseudomonas genus.

\subsection{Experiment 2: Multiplication Process of AMF Consortium on Solid Substrate with Biochar}

The results of AMF root colonization (\%), number of AMF spores and infective AMF potential of substrates at the end of the experiment are summarized in Table 4.

Table 4. Effects of biochar addition on AMF measurements at the end of the multiplication process of an indigenous AMF consortium (T0: 0 wt. \% biochar; T1: 1.5 wt. \% biochar).

\begin{tabular}{|c|c|c|c|}
\hline Treatment & $\begin{array}{c}\text { AMF Root } \\
\text { Colonization (\%) }\end{array}$ & $\begin{array}{c}\text { Number of AMF } \\
\text { Spores } \\
100 \text { g Soil }^{-1}\end{array}$ & $\begin{array}{c}\text { Infective } \\
\text { Mycorrhizal } \\
\text { Propagules } \\
100 \mathrm{~cm}^{3-1}\end{array}$ \\
\hline T0 & $15.5 \pm 2.1$ & $514.6 \pm 59.3$ & $72.4 \pm 32.0$ \\
\hline $\mathrm{T} 1$ & $32.8^{* * *} \pm 5.2$ & $866.9^{* * *} \pm 125.0$ & $161.5^{* *} \pm 80.3$ \\
\hline
\end{tabular}

Data are average of six replicates for AMF root colonization (basil + sorghum) and three replicates for the rest of the parameters \pm SD. Statistically significant differences at ${ }^{* *} p \leq 0.01 ; * * * \leq 0.001$.

The results of this experiment followed the same trend as in Experiment 1, with significant increases $(p \leq 0.05)$ in all measurements carried out in $\mathrm{T} 1$ with respect to T0. Biochar addition increased AMF root colonization by $211 \%$, AMF spores by $168 \%$ and infective AMF potential by $223 \%$ with respect to the treatment without biochar.

It should be highlighted that there were a relatively large number of AMF spores, regardless of the procedure adopted for their quantification (i.e., counts of their isolation through wet sieving and the most probable number of mycorrhizal propagules).

2.5. Experiment 3: Effects of Inoculum Application on Water-Stress Resistance and Development of Lettuce Plants

As expected, results obtained in Experiment 3 showed a strong interaction between water-irrigation conditions and AMF application $(p \leq 0.05)$ for all the parameters studied, with the exception of the SPAD index in $\mathrm{D}_{60}$. This interaction allowed us to analyze the data among the different scenarios of water contributions.

The results of AMF root colonization (\%), number of AMF spores, dry biomass and the SPAD index at the end of the experiment are shown in Table 5. 


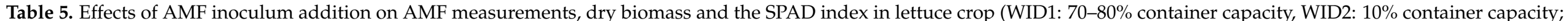

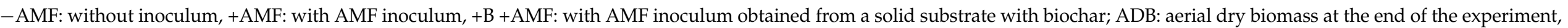
RDB: root dry biomass at the end of the experiment; $\mathrm{D}_{30,50,62}$ : days after sowing; $n$ : number of living plants at the end of the experiment).

\begin{tabular}{|c|c|c|c|c|c|c|c|c|c|}
\hline \multicolumn{2}{|c|}{ Factors } & \multirow{2}{*}{$\begin{array}{c}\text { Root AMF } \\
\text { Coloniz. (\%) } \mathrm{D}_{62}\end{array}$} & \multirow{2}{*}{$\begin{array}{c}\text { Number of AMF } \\
\text { Spores }\end{array}$} & \multicolumn{2}{|c|}{ Dry Biomass } & \multicolumn{3}{|c|}{ SPAD Index } & \multirow{2}{*}{$n$} \\
\hline Irrigation & Inoculum & & & ADB & RDB & $\mathrm{D}_{30}$ & $\mathrm{D}_{50}$ & $D_{62}$ & \\
\hline \multirow{3}{*}{ WID 1} & $-\mathrm{AMF}$ & $1.0 \pm 3.0 \mathrm{c}$ & $2.0 \pm 4.3 \mathrm{c}$ & $2.70 \pm 0.35 \mathrm{ab}$ & $1.28 \pm 0.20 \mathrm{~b}$ & $27.4 \pm 3.2$ & $36.2 \pm 2.1 \mathrm{a}$ & $37.2 \pm 2.5 \mathrm{a}$ & 10 \\
\hline & $+\mathrm{AMF}$ & $13.0 \pm 3.5 b$ & $51.8 \pm 14.3 \mathrm{~b}$ & $3.45 \pm 0.50 \mathrm{ab}$ & $0.93 \pm 0.23 \mathrm{~b}$ & $27.5 \pm 1.2$ & $36.9 \pm 2.0 \mathrm{a}$ & $37.24 \pm 1.8 \mathrm{a}$ & 9 \\
\hline & $+\mathrm{B}+\mathrm{AMF}$ & $24.5 \pm 7.2 \mathrm{a}$ & $144.1 \pm 35.6 \mathrm{ab}$ & $3.71 \pm 0.48 \mathrm{a}$ & $1.26 \pm 0.21 \mathrm{~b}$ & $29.0 \pm 1.0$ & $35.7 \pm 2.3 \mathrm{a}$ & $35.9 \pm 2.6 \mathrm{a}$ & 9 \\
\hline \multirow{3}{*}{ WID 2} & $-\mathrm{AMF}$ & $2.0 \pm 4.2 \mathrm{~b}$ & $1.9 \pm 4.2 \mathrm{c}$ & & $1.25 \pm 0.45 b$ & $28.5 \pm 3.0$ & $21.6 \pm 4.2 \mathrm{c}$ & & 0 \\
\hline & $+\mathrm{AMF}$ & $19.0 \pm 10.0 \mathrm{a}$ & $178.6 \pm 17.9 \mathrm{a}$ & $2.49 \pm 0.21 \mathrm{c}$ & $1.39 \pm 0.39 b$ & $27.6 \pm 3.5$ & $28.1 \pm 3.8 \mathrm{~b}$ & $16.5 \pm 1.1 \mathrm{c}$ & 5 \\
\hline & $+\mathrm{B}+\mathrm{AMF}$ & $24.0 \pm 6.0 \mathrm{a}$ & $201.3 \pm 73.0 \mathrm{a}$ & $2.69 \pm 0.25 b c$ & $1.92 \pm 0.60 \mathrm{a}$ & $27.1 \pm 4.1$ & $33.7 \pm 1.4 \mathrm{a}$ & $17.2 \pm 1.4 \mathrm{~b}$ & 8 \\
\hline
\end{tabular}

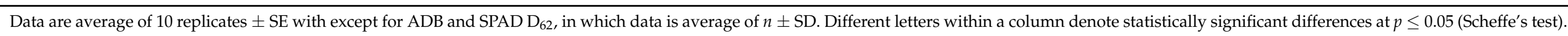


During the first month of crop development, in which all the plants received the same amount of water, no differences were observed in the SPAD index among the treatments.

At the beginning of the second month $\left(\mathrm{D}_{50}\right)$, in which the irrigation dose was reduced (i.e., half of the plants), the SPAD index showed differences between treatments only in those plants that received less water (WID2). Plants growing with AMF inoculum produced with biochar B400 (+B+AMF) showed a significantly higher SPAD index with respect to the plants inoculated with the inoculum produced in the conventional way (+AMF) under low-irrigation conditions. Furthermore, under this irrigation scenario, non-mycorrhized plants showed significantly lower values than mycorrhized plants.

During the period elapsed between $\mathrm{D}_{50}$ and $\mathrm{D}_{62}$, plants without inoculum and under low-irrigation conditions died. Despite this, the root system of the plants was collected, dried, weighed and stained with trypan blue. AMF root colonization was measured because the roots maintained their consistence few days after plants died. These plants developed a total of five leaves, which is a lower value in comparison to the rest of the treatments (in which plants developed six to eight leaves).

At the end of the experiment, both the root AMF colonization and number of AMF spores showed similar trends among treatments. For highly irrigated treatments, AMF activity was significantly higher in the $+\mathrm{B}+\mathrm{AMF}$ treatment. However, no differences between $+\mathrm{AMF}$ treatment and $+\mathrm{B}+\mathrm{AMF}$ were observed under low-irrigation conditions. Regarding the non-inoculated plants, AMF activity was significantly lower in both irrigation conditions. The observed peaks in the AMF activity were probably caused by (i) some contamination coming from the other treatments or (ii) the regeneration of these microorganisms by the substrate itself.

Both the AMF root colonization and number of spores presented higher values in WID2 in comparison to WID1. This confirms the greater development of mycorrhizae under stress conditions as an adaptation strategy.

The aerial and root dry biomass values also showed significant differences between treatments: $+\mathrm{B}+\mathrm{AMF}$ treatment reported the highest values for ADB under both water irrigation treatments. However, these differences between inoculated plants were only statistically significant under lower doses of water. Non-mycorrhized plants exhibited a significant decrease in ADB under well irrigation conditions with respect to AMF treatments.

The root dry biomass (RDB) values showed a clear trend under low-irrigation doses, where $+\mathrm{B}+\mathrm{AMF}$ treatments led to better results. However, for highly irrigated scenarios, the Control treatment without AMF showed similar behavior to +B+AMF mycorrhized plants.

Finally, the leaves nutrient concentrations did not show any significant difference among treatments. Table S5 details the complete information of these results.

\section{Discussion}

Results for AMF root colonization and number of AMF spores in Experiment 1 confirm that biochar application had a significant influence on AMF activity. Slight differences were observed, depending on the texture of the selected substrates.

According to previous publications [22,24,25], the activity of AMF increased after biochar application. However, depending on the experimental conditions and especially on soilnutrient availability, decreases in AMF root colonization have also been reported [18,21]. In this particular experiment, it was confirmed that biochar had a positive effect on AMF development in the sandy-loam texture (S1); nevertheless, the higher activity of mycorrhized roots or number of AMF spores did not result in any marked increase in the biological crop yield, as reported in a previous publication [30]. The obtained results in B600 treatment at high doses in the clay-loam substrate, as mentioned above, showed the minimum value of root colonization and the maximum value for the number of AMF spores, which leads to the conclusion that the sporulation strategy by the mycorrhiza prevailed in this treatment over root colonization. This statement could be related to a stress in the plant. Considering the results obtained 
in a previous publication [30], in which the productive parameters of this experiment were analyzed, no decrease in aerial biomass production was observed for this treatment. However, a lower number of plants fructified under this treatment, meaning that plants did not complete their productive cycle before drying.

Warnock et al. [33], assuming the importance of this community of microorganisms in their studies, elucidated the possible mechanisms that could explain how biochar could alter the total abundance of mycorrhizal fungi in soils and plant roots. In addition to the presence of available phosphorus in the soil, these mechanisms are affected by several factors: (i) modifications in the activity of linked microorganisms, (ii) changes in signaling dynamics between plants and mycorrhizal fungi, and (iii) physical effects related to biochar porosity. Regarding these mechanisms, we relate the higher influence of biochar produced at $400{ }^{\circ} \mathrm{C}$ on AMF activity to the higher volatile content of the biochar with respect to biochar produced at $600{ }^{\circ} \mathrm{C}$. Volatile compounds could alter signaling dynamics in the soil, combined with an increase in water-holding capacity of the affected substrate (sandyloam origin) as it was reported in a previous publication [30]. The multiplication process developed in Experiment 2, where the substrate was composed of sandy-loam soil, as well as the results obtained from Experiment 3 sustain the preliminary results of Experiment 1, where increases in AMF activity in the presence of biochar were observed. It is important to emphasize the role played by the introduction of mycotrophic crops in order to optimize the development of indigenous AMF [15], as was seen when roots of basil and sorghum were combined in the multiplication containers. The average values of root colonization in Experiment 2 were lower than those expected according to the number of AMF spores measured. By comparing these results with those reported in a previous study (which was conducted for different solid substrates [34]), one can conclude that the observed increases in root colonization (caused by biochar addition) are in line with the outcomes reported for other substrates tested (i.e., vermiculite, perlite and volcanic residues).

The observed interactions between biochar and Pseudomonas genus represent a positive finding of this study. These PGPR bacteria appear to be "mycorrhizal helper bacteria" [29] and they were previously studied in order to investigate their relationships with plant nutrition on two fronts: alleviating the abiotic plant stresses [35] and enhancing the host plant defenses [36]. Ordóñez [37] observed a positive interaction between these genera, increasing $\mathrm{P}$ acquisition by plants. Other authors determined the synergistic use of biochar and PGPR for enhancing crop growth under water-deficit conditions [38]. Due to the reduced effects of biochar application on microbial communities observed in this study, further and longer-term studies are required. According to Yadav et al. [6], the aging of biochar could play an important role by increasing microbial biomass activity due to an easier access to carbon sources that are not available in the fresh biochar.

Regarding the enzymatic activity, the results reported here could be complemented by conducting an in-depth study on phosphorus availability in the soil and $\mathrm{pH}$ variations along the experiment. Several studies $[39,40]$ have already observed inverse relationships between inorganic $\mathrm{P}$ availability and phosphatase activity, although this was dependent on initial bioavailable P. Soil $\mathrm{pH}$ also affects the activity of enzymes due to the $\mathrm{pH}$ sensitivity of amino acid functional groups (i.e., at different $\mathrm{pH}$, the conformational preference and spatial structure of amino acids can change). In addition, $\mathrm{pH}$ can also affect enzyme activity by influencing the concentration of inhibitors or activators in the soil solution and the effective concentration of the substrate [41]. Nevertheless, previous publications reported increases in the phosphatase activity after the application of biochar produced at high temperatures $\left(\geq 500^{\circ} \mathrm{C}\right)[42,43]$. From the results reported above, a general trend for phosphatase behavior as a function of biochar application and application rates cannot be established. An apparent effect of B600 application was observed for the sandy-loam substrate in contrast to B400 addition and Control treatment. This influence of the high biochar temperature differs from other previous studies $[44,45]$, in which phosphomonoesterase activity was increased to a greater extent when biochars produced at lower temperatures were applied. 
The suitability of using this biochar as a component of growing media substrate in the multiplication process of AMF was demonstrated in Experiment 2. The search for alternatives to the use of Sphagnum peat as well as the facility to experimenting with biochar under controlled conditions results in a large number of pot-growth-based studies [27]. The physicochemical characteristics of this material have largely been related to some key processes in containerized plant production such as improvement of water retention $[9,46-48]$ and utility as a potential carrier material for delivery of agrochemicals and inoculants [28]. In this sense, several factors influence the scalability of these processes, for which specific life-cycle analyses should be carried out in depth [49]. From the biotechnology perspective, a good microbial carrier should possess essential characteristics such as the capacity to deliver the suitable number of viable microbial cells at the right time [50], which has been reported in this study. Results from different studies show the potential of biochar to be used as an alternative inoculum carrier to peat and vermiculite. Hale et al. [51] tested biochar from different feedstocks and the influence of its characteristics on rhizobacteria survival. According to this study, Ghazi [52] reported a positive performance of biochar to support a Rhizobia inoculant in storage conditions. Various factors influence the scalability of these processes.

Biochar particle size deserves special attention in the present study, in which field conditions were simulated with a previous processing of biochar. Relatively large particle size was used for the pot experiments, with the exception of Experiment 3, in which solid substrate was grinded. One can expect a positive effect of reducing biochar particle size on all (or almost all) the parameters tested. Thus, biochar particle size appears to be an important factor that needs to be further investigated in order to explain the evolution of productive parameters as it has been studied in previous publications [53].

\section{Materials and Methods}

\subsection{Biochar Production, Characterization and Processing}

Vine shoots from winter pruning of vineyards (Vitis vinifera $\mathrm{L}$.) were used as biochar precursor through slow pyrolysis at $400{ }^{\circ} \mathrm{C}$ (B400), and at $600{ }^{\circ} \mathrm{C}(\mathrm{B} 600)$ as the final pyrolysis temperatures. Vine shoots were cut using a domestic chipper into smaller pieces of 4-7 cm length. Pyrolysis experiments were carried out in a fixed-bed laboratory reactor. Information relative to the pyrolysis device, operating conditions and biomass/biochar characterization methodology are detailed in previous publications [30,54].

Both types of biochar were mechanically processed through an automatic agitation system [30] developed at laboratory scale to reproduce the movement in a commercial fertilizer spreader. Different particle sizes (wt. \%) were obtained from this process: $\mathrm{B} 400(7 \%<2 \mathrm{~mm}$; $24 \% 2 \mathrm{~mm}<\mathrm{x}<20 \mathrm{~mm} ; 43 \% 20 \mathrm{~mm}<\mathrm{x}<40 \mathrm{~mm} ; 26 \% \geq 40 \mathrm{~mm}) ; \mathrm{B} 600(4 \%<2 \mathrm{~mm} ; 19 \% 2$ $\mathrm{mm}<\mathrm{x}<20 \mathrm{~mm} ; 55 \% 20 \mathrm{~mm}<\mathrm{x}<40 \mathrm{~mm} ; 22 \% \geq 40 \mathrm{~mm}$ ).

\subsection{Soils Characterization}

Two different agricultural soils with contrasting textures (S1: Soil 1 Calcisol-sandyloam; S2: Soil 2 Cambisol-clay-loam) were selected. Both soils were managed under agroecological techniques and were covered with spontaneous flora at the time of sampling. A 10-point sampling of the first 5-30 $\mathrm{cm}$ was performed to obtain a representative soil sample of the rhizosphere. Samples were air-dried in the laboratory and sieved through a $2 \mathrm{~mm}$ mesh. The methodology adopted for the physicochemical characterization of the soils is detailed in a previous publication [30].

A preliminary biological characterization was conducted and the following parameters were evaluated:

AMF infective potential. (a) The number of AMF infective propagules was quantified using the Most Probable Number (MPN) methodology [55,56], which was previously adopted by Sánchez de Prager et al. [57]. Serial dilutions of soils mixed with a sterilized substrate were established in tray fillers $\left(60 \mathrm{~cm}^{3} /\right.$ filler); a mycotrophic species (barley) was selected for this experiment. Chemically untreated barley seeds were pregerminated and 
previously sterilized in tempered bleach solution (1 vol. \%) for $30 \mathrm{~min}$. One pregerminated seed per tray filler was cultivated for 6 weeks. After this period, plants' roots were separated from the substrate and washed with water, cleared with $2.5 \% \mathrm{KOH}$ for $24 \mathrm{~h}$, acidified with $0.01 \% \mathrm{HCl}$, stained following the methodology proposed by Phillips and Hayman with acidified glycerol $\left(50 \%\right.$ glycerol, $\left.49.95 \% \mathrm{H}_{2} \mathrm{O}, 0.05 \% \mathrm{HCl}\right)$ and $0.05 \%$ trypan blue [58], and cut in 1-2 cm pieces. Root colonization was quantified by the magnified intersect method proposed by McGonigle et al. [59]; (b) AMF spores were isolated from the soil samples following the procedure proposed by Gerdemann and Nicholson [60] and modified by Sieverding [56]. By the nature of the bioassay, the identification of the AMF was carried out morphologically at the genus level. A microscope at up to 400-fold magnification was used as described for glomeromycota classification by Oelh et al. [61] and Sanchez de Prager et al. [57].

Microbiological analyses. For that, $25 \mathrm{~g}$ were sampled of each soil. Samples were decimal diluted in $0.1 \%$ sterile distilled peptone water (Merck, Darmstadt, Germany) and homogenized using a laboratory blender Stomacher 400 Circulator (Seward Laboratory, London, England) for $2 \mathrm{~min}$ at $250 \mathrm{rpm}$. ISO standards were followed for each microbial group enumerated: Mesophilic aerobic microorganisms (4833-1:2014), Pseudomonas genus (13720:2011), and Mycobiota (21527:2008). Actinomycetes species were cultured on Starch Casein Agar (SCA) for 5-7 days at $30^{\circ} \mathrm{C}$ according to Bawazir et al. [62].

\subsection{Experimental Designs and Agronomic Tests Establishment}

Three agronomic tests were carried out with different purposes:

Experiment 1 was carried out to optimize the biochar addition ratio and final pyrolysis temperature with AMF inoculum multiplication purposes. A pot-based experiment growing sorghum crop (Sorghum bicolor L. Moench) was conducted under controlled greenhouse conditions. Polyethylene trays with 12 conical fillers of $650 \mathrm{~cm}^{3}$ volume capacity, $18 \mathrm{~cm}$ deep and $64 \mathrm{~cm}^{2}$ of the upper surface were used for carrying out the bioassay. Three pregerminated seeds per tray filler were placed and carefully watered for 2 months until a thinning was performed (maintaining one plant per tray filler). Sorghum is a classic mycotrophic species widely used as a trap plant in studies and multiplication processes of AMF $[63,64]$. A randomized factorial block design was adopted with three factors as independent variables, as is detailed in Table 6. The duration of the trial was 13 months in which the crop completed two production cycles as is detailed in a previous publication [30].

Table 6. Experimental designs adopted to evaluate the effects of biochar addition as a component of the solid substrate in the multiplication process of AMF.

\begin{tabular}{|c|c|c|c|}
\hline Experiment & Factors & Treatments & Replicates \\
\hline \multirow{3}{*}{1} & $\begin{array}{l}\text { 1. Growing media } \\
\text { texture }\end{array}$ & $\begin{array}{l}\text { S1-substrate } 1 \text { - sandy-loam growing } \\
\text { media } \\
\begin{array}{c}\text { S2-substrate- }-2-\text { clay-loam growing } \\
\text { media }\end{array}\end{array}$ & \multirow{3}{*}{$\begin{array}{l}\text { Five } \\
\text { replicates/treatment: } \\
50 \text { experimental units }\end{array}$} \\
\hline & $\begin{array}{l}\text { 2. Final pyrolysis } \\
\text { temperature }\end{array}$ & $\begin{array}{l}\text { B1-biochar } 1-400^{\circ} \mathrm{C} \\
\text { B2-biochar } 2-600^{\circ} \mathrm{C}\end{array}$ & \\
\hline & $\begin{array}{l}\text { 3. Biochar application } \\
\text { rate }\end{array}$ & $\begin{array}{l}\text { D0-Control-without biochar } \\
\text { D1-1.5 wt. \% } \\
\text { D2-3 wt. \% }\end{array}$ & \\
\hline 2 & $\begin{array}{l}\text { 1. Biochar application } \\
\text { rate }\end{array}$ & $\begin{array}{c}\text { T0 - Control—without biochar } \\
\text { T1-1.5 wt. \% B1 }\end{array}$ & $\begin{array}{l}\text { Three } \\
\text { replicates/treatment: } \\
6 \text { experimental units }\end{array}$ \\
\hline \multirow[t]{2}{*}{3} & 1. Inoculum composition & $\begin{array}{c}\text {-AMF-Control—without inoculum } \\
+\mathrm{AMF}-+ \text { inoculum obtained from } \mathrm{T} 0 \\
+\mathrm{B}+\mathrm{AMF}-+ \text { inoculum obtained from } \\
\mathrm{T} 1\end{array}$ & \multirow[t]{2}{*}{$\begin{array}{l}\text { Ten } \\
\text { replicates/treatment: } \\
60 \text { experimental units }\end{array}$} \\
\hline & 2. Water irrigation dose & $\begin{array}{l}\text { WID1-70-80\% container capacity } \\
\text { WID2-10\% container capacity }\end{array}$ & \\
\hline
\end{tabular}

Experiment 2. Considering the results obtained in Experiment 1, B400 was evaluated as a component of solid substrate for the multiplication process of AMF consortium of 
S1 (sandy-loam texture soil). The process was based on the growth of trap plants in solid substrate. A one-factor design was adopted with 2 levels for the biochar application rate. The distribution of treatments was randomized complete blocks, with 3 replicates for each one (see Table 6). The experimental unit was placed in an $8 \mathrm{~L}$ plastic container $(40 \times 20 \times 16$ $\mathrm{cm}$ ) and was composed of 8 seedlings of sorghum (Sorghum bicolor L. Moench) as host/trap plants combined with 8 seedlings of basil (Ocinum basilicum), which was cut cyclically to avoid overdevelopment (all the seeds were previously sterilized and pregerminated as is described in Section 4.2.). These species were selected considering their high degree of mycorrhization and their adaptation to relatively high temperatures, since this experiment was carried out between the months of March and July (see Table S6 for more information about experimental conditions). At the end of the development cycle, the aerial part of the plants was cut and the solid substrate was processed, cutting the roots into small pieces $(1-2 \mathrm{~cm})$ and forming a homogeneous mixture of all components (roots, soil, fine gravel and peat, as is described in Table S6). Colonized roots and spores present in the substrate are the mycorrhizal propagules that constitute the new inoculum.

Experiment 3. The efficacy of the inoculants obtained in Experiment 2 was evaluated on a lettuce (Lactuca sativa var. Capitata) crop subjected to water-stress conditions. A randomized factorial block design was adopted with two factors as independent variables (see Table 6). The amount of each inoculum added was the equivalent to 50 AMF spores. One pregerminated lettuce seed was established per pot. Plastic pots with $704 \mathrm{~cm}^{3}$ of volume capacity $(8 \times 8 \times 11 \mathrm{~cm})$ were selected for this agronomic test.

The duration of the test was 2 months. During the first 30 days, all the treatments received similar water irrigation inputs (WID1, see Table 6) through gravimetric measurements. From the second month, water irrigation for half of the plants was progressively stopped until $10 \%$ field capacity level for the rest of the experiment (62 days).

Detailed information on the sowing process, substrates composition, growing conditions and monitoring of environmental conditions at the greenhouse is available in Table S6 of supplementary material.

\subsection{Substrate Analysis and Plant Measurements}

For Experiment 1, a detailed report of productive parameters and physicochemical changes in the substrates is collected in a previous publication [30]. Regarding the biological parameters, the following measurements were carried out during the experiment and after the first harvest:

AMF root colonization: three measurements of AMF root colonization were done at different dates after sowing ( 120 days $-\mathrm{D}_{120}, 210$ days $-\mathrm{D}_{210}$, and 330 days $\left.-\mathrm{D}_{330}\right)$ while the crop was established. A 3-point sampling was performed for each pot with a bipartite gouge auger (Eijkelkamp, Netherlands) $200 \mathrm{~mm}$ length and Ø13 $\mathrm{mm}$. Plant roots were separated from substrates and washed with water before staining following the method described in Section 4.2. Direct estimation of AMF root colonization was carried out through microscopic examination following the "magnified intersection method" [58]. The final root system of each plant was processed through the same methodology after washing and drying at $70{ }^{\circ} \mathrm{C}$ to measure total root dry weight [30]; thus, final AMF root colonization was measured 390 days after sowing $\left(\mathrm{D}_{390}\right)$. The quantification of the number of AMF spores was carried out for each pot substrate at the end of the experiment $\left(D_{390}\right)$ following the methodology detailed in Section 4.2. It is important to emphasize that no external mycorrhizal inoculum was added to the tested pots; only the indigenous mycorrhizal consortium of each soil was worked on.

Microbiological analyses: they were performed for each pot substrate at the end of the experiment $\left(\mathrm{D}_{390}\right)$ following the methodology detailed in Section 4.2.

Enzymatic activity: AcdP and AlkP were analyzed based on the colorimetric determination of the $p$-nitrophenol (PNP) released by the enzyme. The methodology followed was proposed by Tabatabai and Bremner [65], and it was adapted at $\mathrm{pH} 5.5$ for AcdP and $\mathrm{pH}$ 11.0 for AlkP. 
For Experiment 2: root colonization at the end of the experiment was measured in a representative number of both basil and sorghum roots. Once the aerial part of the plants was cut, and before grinding the solid substrate, a portion of the central part of the root system of all the plants in each experimental unit was sampled in order to obtain root-colonization information through the stain methodology described in Section 4.2. Three samples from the solid substrate of each experimental unit were reserved for wet sieving analyses and MPN methodology described in Section 4.2.

For Experiment 3: For AMF measurements, the methodologies described in Section 4.2 were conducted at the end of the experiment. Yield was measured by cutting the plants at the end of the experiment and drying in an oven until weight stabilization at $70{ }^{\circ} \mathrm{C}$. Shoot and roots dry weight were differentiated. The analysis of elemental $\mathrm{N}$ (thermic conductivity), $\mathrm{P}$ (spectrometry) and $\mathrm{K}$ (spectrometry) in leaves was conducted once yields were measured. Leaf greenness was measured three times after sowing $\left(D_{30}, D_{50}, D_{62}\right)$ in Experiment 3 as soil-plant analyses development (SPAD) readings (Chlorophyll Meter SPAD-502, Konica Minolta, Osaka, Japan).

\subsection{Statistical Analysis of Results}

Final data were statistically analyzed using the IBM SPSS Statistics v.26 software package. The T-Student test was conducted to analyze results from initial biological characterization and results of Experiment 2. Three-way ANOVA was conducted when the effects of factors and their interactions were studied. Two-way and one-way ANOVA were also conducted in selected cases (e.g., for different textures of growing substrate type and bifactorial experimental designs). Means comparisons were combined with Tukey's and Scheffe's test with a significance level of 0.05. In order to meet the criteria of statistical normality and homoscedasticity, data for the number of AMF spores and the number of infective propagules were transformed into natural logarithms, and the data of root colonization (\%) were transformed into arcsine for statistical analysis.

\section{Conclusions}

The application of vine-shoots-derived biochar modifies the soil biological properties (i.e., AMF activity, microbial communities and enzymatic activity) to different extents depending on the factor being considered (texture substrate, biochar final pyrolysis temperature and application rate). The bioindicators selected in this study were affected by biochar application, despite the large particle size of the biochar used in this experiment. These indicators were more severely affected by the sandy-loam substrate compared to the clay-loam one. The suitability of using this biochar as a component of growing media substrate in the multiplication process of AMF was demonstrated. The combination of biochar and AMF could alleviate plant stress under drought conditions.

Considering the findings reported here, further specific field-scale experiments are required to understand better and assess the effects of vine-shoot-derived biochar application in soils. Results from these studies will also be useful to relate changes in the biological soil activity to physical properties (water-holding capacity, stability of soil aggregates, etc.) and productive parameters, which were slightly affected in this study.

Supplementary Materials: The following are available online at https:/ / www.mdpi.com/article/10 .3390 / plants10050950/s1, Table S1: Proximate, elemental and physicochemical analyses of biochar produced at two different temperatures, Table S2: Results from physicochemical fertility analyses of soils collected for the agronomic test, Table S3: Average values and standard deviation (in brackets) of the effect of growing substrate texture, biochar temperature and application rate on the identified genera of AMF, culturing microbial communities and phosphatase activity in a pot sorghum crop experiment, Table S4: Pearson correlation and p-valor (in brackets) between AMF parameters and microbial communities in a sandy-loam substrate, Table S5: Effect of AMF inoculum addition on nutrient leaves of lettuce, Table S6: Additional information to Section 4.3. Experimental designs and agronomic tests establishment. 
Author Contributions: Conceptualization, F.J.G.-R., J.J.M.-C. and M.d.C.J.-V.; methodology, J.J.M.C., M.d.C.J.-V., P.M.-M., C.M.-D. and M.V.-M.; validation, F.J.G.-R., J.J.M.-C. and M.V.-M.; formal analysis, F.J.G.-R., J.J.M.-C., P.M.-M., C.M.-D. and M.V.-M.; investigation, M.d.C.J.-V., J.J.M.-C., F.J.G.-R., P.M.-M., C.M.-D. and M.V.-M.; resources, M.V.-M., C.M.-D. and P.M.-M.; writing-original draft preparation, M.V.-M.; writing-review and editing, J.J.M.-C., F.J.G.-R., P.M.-M. and C.M.-D.; visualization, M.V.-M. and F.J.G.-R.; supervision, F.J.G.-R., J.J.M.-C., M.d.C.J.-V., P.M.-M. and C.M.-D.; project administration, J.J.M.-C., F.J.G.-R. and M.V.-M.; funding acquisition, F.J.G.-R., J.J.M.-C. and M.V.-M. All authors have read and agreed to the published version of the manuscript.

Funding: This research received funding from the Spanish Ministry of Sciences, Innovation and Universities (ERANET-MED Project MEDWASTE, ref. PCIN-2017-048).

Institutional Review Board Statement: Not applicable.

Informed Consent Statement: Not applicable.

Data Availability Statement: The data presented in this article are available on request from the corresponding author.

Acknowledgments: The authors would like to acknowledge the collaboration and help given by M. Garzón (ICIA), S. Sánchez, S. García and E. Tejedor (CITA); PhD students G. Greco and C. di Stasi, L. López and laboratory technicians of Technological College of Huesca-Universidad de Zaragoza.

Conflicts of Interest: The authors declare no conflict of interest.

\section{References}

1. Hüseyin, B.; Hüdaverdi, G. Drought Stress Due To Climate Change. In Proceedings of the 8th Atmospheric Sciences Symposium (ATMOS 2017), Istanbul, Turkey, 1-4 November 2017.

2. Lehmann, J.; Joseph, S. Biochar for Environmental Management: An Introduction. In Biochar for Environmental Management, Science and Technology; Lehmann, J., Joseph, S., Eds.; Earthscan: London, UK, 2009; pp. 1-12.

3. Paz-Ferreiro, J.; Méndez, A.; Gascó, G.; Guo, M.; He, Z.; Uchimiya, S.M. Application of Biochar for Soil Biological Improvement. In Agricultural and Environmental Applications of Biochar: Advances and Barriers; Guo, M., He, Z., Uchimiya, S.M., Eds.; Soil Science Society of America, Inc.: Madison, MA, USA, 2016; pp. 145-174.

4. Arif, M.; Ilyas, M.; Riaz, M.; Ali, K.; Shah, K.; Ul Haq, I.; Fahad, S. Biochar improves phosphorus use efficiency of organic-inorganic fertilizers, maize-wheat productivity and soil quality in a low fertility alkaline soil. Field Crop. Res. 2017, 214, 25-37. [CrossRef]

5. Song, D.; Xi, X.; Zheng, Q.; Liang, G.; Zhou, W.; Wang, X. Soil nutrient and microbial activity responses to two years after maize straw biochar application in a calcareous soil. Ecotoxicol. Environ. Saf. 2019, 180, 348-356. [CrossRef]

6. Yadav, V.; Jain, S.; Mishra, P.; Khare, P.; Shukla, A.K.; Karak, T.; Singh, A.K. Amelioration in nutrient mineralization and microbial activities of sandy loam soil by short term field aged biochar. Appl. Soil Ecol. 2019, 138, 144-155. [CrossRef]

7. Igalavithana, A.D.; Ok, Y.S.; Usman, A.R.A.; Al-wabel, M.I.; Oleszczuk, P.; Lee, S.S. The Effects of Biochar Amendment on Soil Fertility Could Biochar Be Used as a Fertilizer. In Agricultural and Environmental Applications of Biochar: Advances and Barriers; Guo, M., He, Z., Uchimiya, S.M., Eds.; Soil Science Society of America, Inc.: Madison, MA, USA, 2016; pp. 123-144.

8. De Melo Carvalho, M.T.; De Holanda Nunes Maia, A.; Madari, B.E.; Bastiaans, L.; Van Oort, P.A.J.; Heinemann, A.B.; Da Silva, M.A.S.; Petter, F.A.; Marimon, B.H.; Meinke, H. Biochar increases plant-available water in a sandy loam soil under an aerobic rice crop system. Solid Earth 2014, 5, 939-952. [CrossRef]

9. Lei, O.; Zhang, R. Effects of biochars derived from different feedstocks and pyrolysis temperatures on soil physical and hydraulic properties. J. Soils Sediments 2013, 13, 1561-1572. [CrossRef]

10. Zhang, Q.; Song, Y.; Wu, Z.; Yan, X.; Gunina, A.; Kuzyakov, Y.; Xiong, Z. Effects of six-year biochar amendment on soil aggregation, crop growth, and nitrogen and phosphorus use efficiencies in a rice-wheat rotation. J. Clean. Prod. 2020, 242, 118435. [CrossRef]

11. Xing, D.; Magdouli, S.; Zhang, J.; Koubaa, A. Microbial remediation for the removal of inorganic contaminants from treated wood: Recent trends and challenges. Chemosphere 2020, 258, 127429. [CrossRef] [PubMed]

12. Chica, A.; Artola, A.; Rosal, A.; Solé-Mauri, F.; Fernandez, F.; García, J.; Dios, M.; Díaz, M.; Ramón, G.; Font, X. De Residuo a Recurso, El camino hacia la Sostenibilidad. In III. Recursos Orgánicos. Aspectos Agronómicos y Mediambientales. España. Capítulo 8: Enmiendas Orgánicas y de Nueva Generación: Biochar y Otras Biomoléculas; Red Española de Compostaje, Ed.; Mundi-Prensa: Madrid, Spain, 2015; p. 290.

13. Jaizme-Vega, M.C. Los microorganismos rizosféricos: Bioindicadores de sostenibilidad en suelos de tomate en las Islas Canarias. AE. Revista Agroecológica de Divulgación 2015, 20, 18-19.

14. Alizadeh, V.; Shokri, V.; Soltani, A.; Yousefi, M.A. Effects of Climate Change and Drought-Stress on Plant Physiology. Int. J. Adv. Biol. Biomed. Res. 2014, 2, 468-472.

15. Barea, J.M.; Palenzuela, J.; Cornejo, P.; Sánchez-Castro, I.; Navarro-Fernández, C.; Lopéz-García, A.; Estrada, B.; Azcón, R.; Ferrol, N.; Azcón-Aguilar, C. Ecological and functional roles of mycorrhizas in semi-arid ecosystems of Southeast Spain. J. Arid Environ. 2011, 75, 1292-1301. [CrossRef] 
16. Ruíz-lozano, J.M.; Perálvarez, C.; Aroca, R. The application of a treated sugar beet waste residue to soil modifies the responses of mycorrhizal and non mycorrhizal lettuce plants to drought stress. Plant Soil 2011,153-166. [CrossRef]

17. Jaafar, N.M. Biochar as a Habitat for Arbuscular Mycorrhizal Fungi. In Mycorrhizal Fungi: Use in Sustainable Agriculture and Land Restoration. Soil Biology; Solaiman, Z., Abbott, L., Varma, A., Eds.; Springer: Berlin/Heidelberg, Germany, 2014 ; Volume 41. [CrossRef]

18. Jaizme-Vega, M.C. Microorganismos funcionales del suelo. Su papel en el manejo ecológico de los secanos. In Agricultura Ecológica en Secano. Soluciones Sostenibles en Ambientes Mediterráneos; Ministerio de Medio Ambiente y Medio Rural y Marino, Ed.; Mundi-Prensa: Madrid, Spain, 2011; pp. 417-439.

19. Warnock, D.D.; Mummey, D.L.; McBride, B.; Major, J.; Lehmann, J.; Rillig, M.C. Influences of non-herbaceous biochar on arbuscular mycorrhizal fungal abundances in roots and soils: Results from growth-chamber and field experiments. Appl. Soil Ecol. 2010, 46, 450-456. [CrossRef]

20. Amendola, C.; Montagnoli, A.; Terzaghi, M.; Trupiano, D.; Oliva, F.; Baronti, S.; Miglietta, F.; Chiatante, D.; Scippa, G.S. Short-term effects of biochar on grapevine fine root dynamics and arbuscular mycorrhizae production. Agric. Ecosyst. Environ. 2017, 239, 236-245. [CrossRef]

21. Cobb, A.B.; Wilson, G.W.T.; Goad, C.L.; Grusak, M.A. Influence of alternative soil amendments on mycorrhizal fungi and cowpea production. Heliyon 2018, 4, e00704. [CrossRef]

22. LeCroy, C.; Masiello, C.A.; Rudgers, J.A.; Hockaday, W.C.; Silberg, J.J. Nitrogen, biochar, and mycorrhizae: Alteration of the symbiosis and oxidation of the char surface. Soil Biol. Biochem. 2013, 58, 248-254. [CrossRef]

23. Vanek, S.J.; Lehmann, J. Phosphorus availability to beans via interactions between mycorrhizas and biochar. Plant Soil 2015, 395, 105-123. [CrossRef]

24. Ameloot, N.; Sleutel, S.; Das, K.C.; Kanagaratnam, J.; de Neve, S. Biochar amendment to soils with contrasting organic matter level: Effects on N mineralization and biological soil properties. GCB Bioenergy 2015, 7, 135-144. [CrossRef]

25. Solaiman, Z.M.; Abbott, L.K.; Murphy, D.V. Biochar phosphorus concentration dictates mycorrhizal colonisation, plant growth and soil phosphorus cycling. Sci. Rep. 2019, 9, 1-11. [CrossRef]

26. Hammer, E.C.; Balogh-Brunstad, Z.; Jakobsen, I.; Olsson, P.A.; Stipp, S.L.S.; Rillig, M.C. A mycorrhizal fungus grows on biochar and captures phosphorus from its surfaces. Soil Biol. Biochem. 2014, 77, 252-260. [CrossRef]

27. Medynska-Juraszek, A.; Cwielag-Piasecka, I. Biochar as a growing media component. In Biochar as a Renewable-Based Material: With Applications in Agriculture, the Environment and Energy; Manyà, J.J., Gascó, G., Eds.; World Scientific Publishing Europe Ltd.: London, UK, 2021; pp. 85-104.

28. Sashidhar, P.; Kochar, M.; Singh, B.; Gupta, M.; Cahill, D.; Adholeya, A.; Dubey, M. Biochar for delivery of agri-inputs: Current status and future perspectives. Sci. Total Environ. 2020, 703, 134892. [CrossRef]

29. Medina Peñafiel, A. Estudio de la Interacción Entre Inoculantes Microbianos y Residuos Agroindustriales Biotransformados Para su uso en Estrategias de Revegetación y Bioremediación. Ph.D. Thesis, Universidad de Granada, Granada, Spain, 2006.

30. Videgain-Marco, M.; Marco-Montori, P.; Martí-Dalmau, C.; Jaizme-Vega, M.D.C.; Manyà-Cervelló, J.J.; García-Ramos, F.J. Effects of Biochar Application in a Sorghum Crop under Greenhouse Conditions: Growth Parameters and Physicochemical Fertility. Agronomy 2020, 10, 104. [CrossRef]

31. Jaizme-vega, M.C.; Rodríguez-romero, A.S. Integración de microorganismos benéficos (Hongos micorrícicos y bacterias rizosféricas) en agrosistemas de las Islas Canarias. Agroecología 2008, 3, 33-40.

32. Qayyum, M.F.; Haider, G.; Iqbal, M.; Hameed, S.; Ahmad, N.; ur Rehman, M.Z.; Majeed, A.; Rizwan, M.; Ali, S. Effect of alkaline and chemically engineered biochar on soil properties and phosphorus bioavailability in maize. Chemosphere 2021, 266. [CrossRef] [PubMed]

33. Warnock, D.D.; Lehmann, J.; Kuyper, T.W.; Rillig, M.C. Mycorrhizal responses to biochar in soil—Concepts and mechanisms. Plant Soil 2007, 300, 9-20. [CrossRef]

34. González, A.J.H. Posibilidades de la Producción de Inóculo de Micorrizas Vesiculo-Arbusculares Sobre Sustratos Canarios de Origen Volcánico; Trabajo fin de carrera Universidad de La Laguna: Tenerife, Spain, 1993; p. 124.

35. Etesami, H.; Maheshwari, D.K. Use of plant growth promoting rhizobacteria (PGPRs) with multiple plant growth promoting traits in stress agriculture: Action mechanisms and future prospects. Ecotoxicol. Environ. Saf. 2018, 156, 225-246. [CrossRef] [PubMed]

36. Pérez-De-Luque, A.; Tille, S.; Johnson, I.; Pascual-Pardo, D.; Ton, J.; Cameron, D.D. The interactive effects of arbuscular mycorrhiza and plant growth-promoting rhizobacteria synergistically enhance host plant defences against pathogen. Sci. Rep. 2017, 7, 1-10. [CrossRef]

37. Ordoñez, Y. Interacción sinérgica entre hongos formadores de micorrizas arbusculares—Pseudomonas fluorescens y su relación en la nutrición vegetal de fósforo. In Trabajo de Grado, Magíster en Ciencias; Facultad de Ciencias, Maestría en microbiología; Universidad Nacional de Colombia: Bogotá, Colombia, 2009.

38. Nadeem, S.M.; Imran, M.; Naveed, M.; Khan, M.Y.; Ahmad, M.; Zahir, Z.A.; Crowley, D.E. Synergistic use of biochar, compost and plant growth-promoting rhizobacteria for enhancing cucumber growth under water deficit conditions. J. Sci. Food Agric. 2017, 97, 5139-5145. [CrossRef]

39. Olander, L.P.; Vitousek, P.M. Regulation of soil phosphatase and chitinase activity by N and P availability. Biogeochemistry 2000, 49, 175-190. [CrossRef] 
40. Treseder, K.K.; Vitousek, P.M. Effects of soil nutrient availability on investment in acquisition of N and P in Hawaiian rain forests. Ecology 2001, 82, 946-954. [CrossRef]

41. Dick, W.A.; Cheng, L.; Wang, P. Soil acid and alkaline phosphatase activity as pH adjustment indicators. Soil Biol. Biochem. 2000, 32, 1915-1919. [CrossRef]

42. Paz-Ferreiro, J.; Gascó, G.; Gutiérrez, B.; Méndez, A. Soil biochemical activities and the geometric mean of enzyme activities after application of sewage sludge and sewage sludge biochar to soil. Biol. Fertil. Soils 2012, 48, 511-517. [CrossRef]

43. Masto, R.E.; Kumar, S.; Rout, T.K.; Sarkar, P.; George, J.; Ram, L.C. Biochar from water hyacinth (Eichornia crassipes) and its impact on soil biological activity. Catena 2013, 111, 64-71. [CrossRef]

44. Khadem, A.; Raiesi, F. Response of soil alkaline phosphatase to biochar amendments: Changes in kinetic and thermodynamic characteristics. Geoderma 2019, 337, 44-54. [CrossRef]

45. Jin, Y.; Liang, X.; He, M.; Liu, Y.; Tian, G.; Shi, J. Manure biochar influence upon soil properties, phosphorus distribution and phosphatase activities: A microcosm incubation study. Chemosphere 2016, 142, 128-135. [CrossRef]

46. Tanure, M.M.C.; da Costa, L.M.; Huiz, H.A.; Fernandes, R.B.A.; Cecon, P.R.; Pereira Junior, J.D.; da Luz, J.M.R. Soil water retention, physiological characteristics, and growth of maize plants in response to biochar application to soil. Soil Tillage Res. 2019, 192, 164-173. [CrossRef]

47. Paneque, M.; De la Rosa, J.M.; Franco-Navarro, J.D.; Colmenero-Flores, J.M.; Knicker, H. Effect of biochar amendment on morphology, productivity and water relations of sunflower plants under non-irrigation conditions. Catena 2016, 147, $280-287$. [CrossRef]

48. Aller, D.; Rathke, S.; Laird, D.; Cruse, R.; Hatfield, J. Impacts of fresh and aged biochars on plant available water and water use efficiency. Geoderma 2017, 307, 114-121. [CrossRef]

49. Sara, M.; Rouissi, T.; Brar, S.K.; Blais, J.F. Life Cycle Analysis of Potential Substrates of Sustainable Biorefinery; Elsevier Incorporation: Amsterdam, The Netherlands, 2016; ISBN 9780128029800.

50. Bashan, Y.; de-Bashan, L.E.; Prabhu, S.R.; Hernandez, J.P. Advances in plant growth-promoting bacterial inoculant technology: Formulations and practical perspectives (1998-2013). Plant Soil 2014, 378, 1-33. [CrossRef]

51. Hale, L.; Luth, M.; Crowley, D. Biochar characteristics relate to its utility as an alternative soil inoculum carrier to peat and vermiculite. Soil Biol. Biochem. 2015, 81, 228-235. [CrossRef]

52. Ghazi, A. Potential for Biochar as an Alternate Carrier to Peat Moss for the Preparation of Rhizobia Bio Inoculum. Microbiol. Res. J. Int. 2017, 18, 1-9. [CrossRef]

53. Liang, C.; Gascó, G.; Fu, S.; Méndez, A.; Paz-Ferreiro, J. Biochar from pruning residues as a soil amendment: Effects of pyrolysis temperature and particle size. Soil Tillage Res. 2016, 164, 3-10. [CrossRef]

54. Greco, G.; Videgain, M.; Di Stasi, C.; González, B.; Manyà, J.J. Evolution of the mass-loss rate during atmospheric and pressurized slow pyrolysis of wheat straw in a bench-scale reactor. J. Anal. Appl. Pyrolysis 2018, 136, 18-26. [CrossRef]

55. Porter, W.M. The "most probable number" method for enumerating infective propagules of vesicular arbuscular mycorrhizal fungi in soil. Aust. J. Soil Res. 1979, 17, 515-519. [CrossRef]

56. Sieverding, E. Vesicular-Arbuscular Mycorrhiza Management in Tropical Agrosystems; GTZ, D., Ed.; TZ-Verlagsgesellschaft: Eschborn, Germany, 1991.

57. De Prager, S. Metodologías Básicas Para el Trabajo con Micorriza Arbuscular y Hongos Formadores de Micorriza Arbuscular; Universidad Nacional de Colombia, Ed.; Universidad Nacional de Colombia: Palmira, Colombia, 2016; p. 139. ISBN 9789588095608.

58. Phillips, N.C.; Hayman, D.S. Improved procedures for clearing roots and staining parasitic and vesicular-arbuscular mycorrhizal fungi for rapid assessment to infection. Trans. Br. Mycol. Soc. 1970, 55, 158-161. [CrossRef]

59. McGonigle, T.P.; Miller, M.H.; Evans, D.G.; Fairchild, G.L.; Swan, J.A. A new method which gives an objective measure of colonization of roots by vesicular-Arbuscular mycorrhizal fungi. New Phytol. 1990, 115, 495-501. [CrossRef]

60. Gerdemann, J.W.; Nicholson, T.H. Spores of mycorrhizal Endogone species extracted from soil by wet sieving and decanthing. Trans. Br. Mycol. Soc. 1963, 46, 235-244. [CrossRef]

61. Oehl, F.; Sieverding, E.; Palenzuela, J.; Ineichen, K.; Alves da Silva, G. Advances in Glomeromycota taxonomy and classification. IMA Fungus 2011, 2, 191-199. [CrossRef]

62. Bawazir, A.M.A.; Shivanna, G.B.; Shantaram, M. Impact of Different Media for Growth and Production of Different Soluble Pigments in Actinomycetes Isolated from Soils of Hadhramout, Yemen. Eur. J. Biomed. 2018, 5, 615-619.

63. Yao, Q.; Gao, J.L.; Zhu, H.H.; Long, L.K.; Xing, Q.X.; Chen, J.Z. Evaluation of the potential of trap plants to detect arbuscular mycorrhizal fungi using polymerase chain reaction-denaturing gradient gel electrophoresis analysis. Soil Sci. Plant Nutr. 2010, 56, 205-211. [CrossRef]

64. Jaizme-vega, M.C. Las Micorrizas, Una Estrategia Agroecológica Para Optimizar la Calidad de los Cultivos; Universidad de la Laguna, Instituto Canario de Investigaciones Agrarias, Phytoma España S.L., Eds.; Phytoma España S.L.: Valencia-San Cristóbal de la Laguna (Tenerife), Spain, 2019; p. 112. ISBN 978-84-946691-5-6.

65. Tabatabai, M.A.; Bremner, J.M. Use of p-nitrophenyl phosphate for assay of soil phosphatase activity. Soil Biol. Biochem. 1969, 1, 301-307. [CrossRef] 